\title{
De danske og engelske sundhedsreformer: En test af New Public Management-bølgens indhold og betydning
}

\begin{abstract}
Med udgangspunkt i de danske og engelske sundhedsreformer, der er gennemført i slutningen af 1980'eme og begyndelsen af 1990'erne, belyser artiklen tre aspekter af ..New Public Management"-bølgen. Er der for det forste tale om nye forvaltningsmassige principper? Er reformerne, for det andet, rent faktisk blevet gennemført? Og har reformerne, for det tredje, virket efter den erklærede hensigt med „New Public Management“-reformerne. I artiklen argumenteres der for, at „New Public Management"-reformerne kun i nogen grad lever op til sit navn og kun i et vist omfang er blevet gennemført. Endelig har reformerne ikke bidraget til at forøge effektiviteten af sundhedsvæsenet i hverken Danmark eller England - snarere tværtimod.
\end{abstract}

"New Public Management" er ikke et synderligt veldefineret begreb. New Public Management - eller NPM, som det ofte indforstået forkortes til - omfatter tilsyneladende en lang række meget forskellige offentlige organisationsformer. I en større undersøgelse af udviklingstendenserne i de finske kommuner fremgår det eksempelvis, at New Public Management- foranstaltninger omfatter: Resultatenheder, BU-modeller, $\mathrm{k} ø \mathrm{~b}$ fra private, køb fra kommuner, kommunale fællesforetagender, offentlige selskaber, koncern- og kvalitetsledelse, brugerbetaling, personaleinddragelse, valgfrihed mellem offentlige institutioner, støtte til brugerorganisationer, brugerdemokrati, brugertilkobling, lokal- og sektoraftaler (Ståhlberg, 1996). Disse eksempler på New Public Management-foranstaltninger er næppe en udtømmende opremsning, hvilket i hvert fald rejser spørgsmålet om, hvad der ikke kan betegnes som New Public Management-initiativer. Som det ligeledes fremgår af eksemplerne er det ikke kun forkortelsen af NPM, der fordrer en vis indforståelse det gælder ligeledes flere af de organisationsformer, der er omfattet af begrebet. Hvad der eksempelvis karakteriserer "resultatenheder", "kvalitetsledelse" eller "bru- gertilkopling", er ikke uden videre indlysende. På den baggrund kan det måske i endnu højere grad synes overraskende, at ikke mindre end 60 pct. af de godt to tusinde kommunalpolitikere og ledende kommunale embedsmænd, der indgår i den finske undersøgelse, anså netop "resultatenheder", "kvalitetsledelse" og "brugertilkobling" for at være vigtige eller meget vigtige NPMforanstaltninger.

På et mere overordnet niveau har Hood (1991) ligeledes søgt at indkredse, hvad der karakteriserer New Public Management. Hood identificerer syv elementer i New Public Management - begrebet:

1. "Hands on management"- hvorved der forstås en mere aktiv ledelse, der har større frihed til at lede og et større ansvar for resultatet af deres ledelsesindsats.

2. "Explicit standards and measures of performance" - dvs. at der etableres mål og resultatkrav, der kan kvantificeres.

3. "Output control"- dvs. en stærkere sammenhæng mellem budget og aktivitet.

4. Disaggregering og decentralisering dvs. adskillelse af køber- og producentrollen inden for den offentlige sek- 


\title{
De danske og engelske sundhedsreformer: En test af New Public Management-bølgens indhold og betydning
}

\begin{abstract}
Med udgangspunkt i de danske og engelske sundhedsreformer, der er gennemført i slutningen af 1980'eme og begyndelsen af 1990'erne, belyser artiklen tre aspekter af ..New Public Management"-bølgen. Er der for det forste tale om nye forvaltningsmassige principper? Er reformerne, for det andet, rent faktisk blevet gennemført? Og har reformerne, for det tredje, virket efter den erklærede hensigt med „New Public Management“-reformerne. I artiklen argumenteres der for, at „New Public Management"-reformerne kun i nogen grad lever op til sit navn og kun i et vist omfang er blevet gennemført. Endelig har reformerne ikke bidraget til at forøge effektiviteten af sundhedsvæsenet i hverken Danmark eller England - snarere tværtimod.
\end{abstract}

"New Public Management" er ikke et synderligt veldefineret begreb. New Public Management - eller NPM, som det ofte indforstået forkortes til - omfatter tilsyneladende en lang række meget forskellige offentlige organisationsformer. I en større undersøgelse af udviklingstendenserne i de finske kommuner fremgår det eksempelvis, at New Public Management- foranstaltninger omfatter: Resultatenheder, BU-modeller, $\mathrm{k} ø \mathrm{~b}$ fra private, køb fra kommuner, kommunale fællesforetagender, offentlige selskaber, koncern- og kvalitetsledelse, brugerbetaling, personaleinddragelse, valgfrihed mellem offentlige institutioner, støtte til brugerorganisationer, brugerdemokrati, brugertilkobling, lokal- og sektoraftaler (Ståhlberg, 1996). Disse eksempler på New Public Management-foranstaltninger er næppe en udtømmende opremsning, hvilket i hvert fald rejser spørgsmålet om, hvad der ikke kan betegnes som New Public Management-initiativer. Som det ligeledes fremgår af eksemplerne er det ikke kun forkortelsen af NPM, der fordrer en vis indforståelse det gælder ligeledes flere af de organisationsformer, der er omfattet af begrebet. Hvad der eksempelvis karakteriserer "resultatenheder", "kvalitetsledelse" eller "bru- gertilkopling", er ikke uden videre indlysende. På den baggrund kan det måske i endnu højere grad synes overraskende, at ikke mindre end 60 pct. af de godt to tusinde kommunalpolitikere og ledende kommunale embedsmænd, der indgår i den finske undersøgelse, anså netop "resultatenheder", "kvalitetsledelse" og "brugertilkobling" for at være vigtige eller meget vigtige NPMforanstaltninger.

På et mere overordnet niveau har Hood (1991) ligeledes søgt at indkredse, hvad der karakteriserer New Public Management. Hood identificerer syv elementer i New Public Management - begrebet:

1. "Hands on management"- hvorved der forstås en mere aktiv ledelse, der har større frihed til at lede og et større ansvar for resultatet af deres ledelsesindsats.

2. "Explicit standards and measures of performance" - dvs. at der etableres mål og resultatkrav, der kan kvantificeres.

3. "Output control"- dvs. en stærkere sammenhæng mellem budget og aktivitet.

4. Disaggregering og decentralisering dvs. adskillelse af køber- og producentrollen inden for den offentlige sek- 
tor og decentralisering af budgetansvaret, for eksempel. rammebudgettet på institutionsniveau med stor dispositionsfrihed ("one-line-budgets").

5. "Competetion"- både konkurrence internt i den offentlige sektor og med den private sektor, for eksempel ved udliciteringer.

6. "Private sector styles of management"hvilket for eksempel indebærer større frihed til at rekuttere personale evt. uden for organisationen; større brug af PR og marketing.

7. "Discipline and parsimony" - dvs. et øget fokus på omkostningskontrol eller besparelser, herunder at modstå pres fra personaleorganisationer $\mathrm{g}$ fagforeninger.

Hoods definition af New Public Management er heller ikke helt problemfri. På samme måde som med Ståhlbergs eksempler på New Public Management-foranstaltninger er det ikke umiddelbart indlysende, hvad der for eksempel forstås ved "hands on"- "private style management". I forlængelse heraf kan det ligeledes være svært at vurdere, om kategorierne er gensidigt udelukkende, og hvorvidt de enkelte elementer beskriver den samme eller forskellige dimensioner i New Public Management-begrebet. Det forekommer således som om Hoods syvende element - det øgede fokus på omkostningskontrol og besparelser - skal opnås netop ved at iværksætte de første seks foranstaltninger.

Uanset de kritiske bemærkninger om indholdet og definitionen af begrebet New Public Management er der formentlig ingen tvivl om, at såvel Ståhlberg som Hood beskæftiger sig med et emne, der er centralt i forhold til udviklingen af den offentlige sektor $i$ en lang række vestlige lande: Der har i hvert fald været megen tale om, at den offentlige sektor og de offentlige institutioner har været genstand for en række reformbestræbelser, der kan henføres til den løseligt definerede kategori New Public Management-foranstaltninger.

Det åbenlyse kritiske mod-spørgsmål er, hvor meget der egentlig er om snakken om de omfattende New Public Managementreformer. Dette spørgsmål kan deles op i tre underspørgsmål. For det første, hvorvidt New Public Management-bølgen indeholder nye forvaltningsmæssige principper, eller om der er tale om en reformulering af klassiske læresætninger. For det andet rejser det spørgsmålet, hvorvidt der rent faktisk er tale om en bølge i den forstand, at de offentlige forvaltninger er blevet reformeret, og at reformeme er foretaget med udgangspunkt i New Public management-tankegodset - uanset de forskelle, der er mellem de enkelte landes offentlige sektorer. Et tredje og helt centralt spørgsmål er, om reformerne, i det omfang de overhovedet er gennemført, rent faktisk har levet op til New Public Management-målsætningen og har haft en effekt på den offentlige sektors udgifts- og produktivitetsudvikling.

Denne artikel søger at give et svar på disse spørgsmål med udgangspunkt i de reformer, der er gennemført inden for sundhedsvæsenet i England og Danmark i 1980'erne og 1990'erne. Det er således en mini-test af indholdet $o g$ betydningen af New Public Management-bølgen, der er artiklens sigte. Selv om undersøgelsen er begrænset til reformerne $i$ én sektor $i$ to lande, giver det et fingerpeg om, hvorvidt reforminitiativerne har et fællesindhold, og om dette fællesindhold i givet fald har New Public Management-karakter. Fordelen ved at begrænse undersøgelsen til England og Danmark er ydermere, at det ligeledes giver et fingerpeg om, hvorvidt de basale strukturelle forskelle på de to landes sundhedsvæsener har betydning for den effektivitet, hvormed forslagene kan implemen- 
teres. Den i denne sammenhæng interessante forskel på det engelske og danske sundhedsvæsen er placeringen af den politiske kompetence: Det engelske sundhedsvæsen er et statsligt, centralt styret system, mens det danske sundhedsvæsen er et stærkt decentraliseret, amtskommunalt system. Bortset herfra er det danske og engelske sundhedsvæsen på mange måder organiseret efter de samme principper. Det galder finansieringen, der begge steder overvejende er baseret på skatter. Det gælder ligeledes driften af hospitalerne, der i begge lande er offentligt drevne institutioner, der i sidste instans er politisk ledede.

\section{Reformerne af det engelske sundheds- væsen i 1980'erne og 1990'erne}

Den mest omfattende reform af det engelske sundhedsvæsen blev skitseret i regeringsbetænkningen "Working for Patients" (Department of Health, 1989), der blev gennemført fra og med 1991. Men også før denne omfattende reform blev der gennemført en række mindre ændringer af det engelske sundhedsvæsen, der i variende grad kan indpasses i det løse New Public Management-begreb.

Det engelske sundhedsvæsen er et statsligt system, hvilket i princippet vil sige, at sundhedsministeren er den øverste overordnede for de ansatte i det engelske sundhedsvæsen, det såkaldte "National Health Service" (NHS). Uanset at NHS er et statsligt system, har det været organiseret efter geografiske kriterier: Landet er opdelt i en række regioner, der befolkningsmæssigt omtrent svarer til størrelsen af Danmarks befolkning. Den enkelte region er yderligere opdelt i distrikter, der stort set svarer til størrelsen af et dansk amt. Indtil 1982 var NHS yderligere opdelt i endnu et overordnet, geografisk organisatorisk lag - de såkaldte "Area Health Authorities", der var skudt ind imellem det regionale niveau og distriktsniveauet. Afskaffelsen af disse Area Health Authorities kvalificerer næp til betegnelsen et New Public Management-initiativ: Indretning og ændringer af organisationer efter funktion, proces, klientel og geografiske principper er klassiske kriterier for udformningen af den offentlige forvaltning (Gulick, 1937).

1982-reformen indeholdt imidlertid også tiltag, der i højere grad falder ind under New Public Management-begrebet, idet beslutningskompetencen til en vis grad blev decentraliseret, således at de enkelte distrikter fik større dispositionsfrihed inden for deres budgetramme. Der blev samtidig indført et system med såkaldte "annual reviews" af regionerne og senere distrikterne, hvor en række "performance-indicators" indgik $i$ vurderingen af regionernes og distrikternes virksomhed. Performanceindikatorerne omfattede tre hovedområder: Gennemsnitlige ydelsesomkostninger (for eksempel for en sengedag, en behandling, en kostdag, og rengøringsudgiften pr. kvadratmeter), personaleindsatsen (for eksempel antallet af sygeplejersker i forhold til antal indlæggelser, den relative fordeling af uddannet og ikke-uddannet personale) samt endelig en række indikatorer for den kliniske aktivitet (antal indlæggelser, sengedage og ambulante; ventelister, gennemsnitlig liggetid mv.)(NAHA, 1985). Det overordnede formål med indførelsen af den årlige vurdering af regionernes og distrikternes virksomhed - herunder udarbejdelsen af nøgletal for de enkelte regioner og distrikter-var at forøge omkostningseffektiviteten i det engelske sundhedsvæsen. Fndringeme øgede muligheden for at kontrollere regionernes og distrikternes virksomhed og fastholde dem på ansvaret for driften af sundhedsvæsenet inden for deres område. Ideen var også, at udarbejdelsen af nøgletallene skulle øge deres tilskyndelse til at 
forbedre deres position i forhold til andre sammenlignelige regioner og distrikter. Dette aspekt ved udarbejdelsen af nøgletallene blev understreget ved, at de enkelte regioners og distrikters placering på de enkelte indikatorer blev offentliggjort i de såkaldte "League-tables".

Ledelsesforholdene inden for det engelske sundhedsvæsen blev ligeledes sat på dagsordenen i 1983. I en regeringsbetænkning (Department of Health, 1983a) - udarbejdet af folk med tilknytning til det private erhvervsliv og med direktøren for supermarkedskæden, Sainsbury, Roy Griffiths i spidsen-blev ledelsesstrukturen i NHS kritiseret skarpt for at medføre en uklar placering af ansvaret og kompetencen for driften af sundhedsvæsenet. Betænkningen hældede til den opfattelse, at $i$ den daværende ledelsesstruktur var der reelt ikke nogen, der havde ansvaret for noget som helst. Med direkte reference til en af Englands sundhedsvæsens ikoner udtrykkes vurderingen i en prægnant passage om Florence Nightingale: Hvis hun i dag gik rundt med sin lampe i NHS's korridorer, ville hun næppe kunne finde nogen med et ledelsesansvar.

Hovedansvaret for det uklare eller fraværende ledelsesansvar var efter betænkningens opfattelse en konsekvens af det daværende såkaldte konsensus-management system. Konsensus-management systemet indebar, at ledelsen på regions- og distriktsniveau var en gruppe, der bestod af administratorer, læger og sygeplejersker. Ledelsesbeslutninger, der for eksempel kun havde konsekvenser for sygeplejegruppen, blev suverænt truffet af sygeplejerepræsentanten $i$ ledelsesgruppen. Andre beslutninger, der havde bredere konsekvenser, skulle træffes i enighed. Konsensus-systemet indeholdt ligeledes en omfattende række procedurer for høring af de lægelige organisationer og repræsenter for de lokale, kommunale myndigheder. Griffiths-betzenknin- gen anbefalede, at der i stedet blev indført en ledelsesstruktur med én leder, en "general manager", der havde det overordnede ansvar på hvert af niveauerne. Betænkningen indeholdt to andre anbefalinger: For det første, at udskille det egentlige driftsansvar for sundhedsvæsenet fra sundhedsministeriet til en særlig driftsorganisation på det centrale statslige niveau. For det andet blev det foreslået, at budgetansvaret blev yderligere decentraliseret fra distrikterne til hospitals- og afdelingsniveauet, og at lægerne på hospitalerne ud over det kliniske ansvar også fik et ansvar og en kompetence i forhold til de økonomiske konsekvenser af deres kliniske dispositioner. Bortset fra det sidste forslag om en integration af et fagligt og økonomisk ansvar kan det igen være svært at se det revolutionerende nye i forslagene: Klare og entydige ansvars- og kompetenceregler, herunder en så klar adskillelse af politik og forvaltning som muligt, er klassiske læresæetninger inden for organisations- og bureaukratiteorien, der i hvert fald kan føres tilbage til Weber.

Anderledes forholder det sig med bestrabelsen på at inddrage private organisationer og leverandører i løsningen af offentlige driftsopgaver. Dette er et af de mere originale New Public Management-initiativer. Ikke fordi, der er noget nyt i, at den private sektor i større eller mindre grad er involveret $i$ løsningen af sundhedsopgaver. Det er ikke tilfældet, heller ikke i England. Lige siden etableringen af NHS i slutningen af 1940'erne har der været en privat eller uafhængig sundhedssektor, der i et vist omfang har leveret sundhedsydelser på kontrakt til det offentlige sundhedsvæesen. Den private sektor har ligeledes været underleverandør til det offentlige sundhedsvæsen på afgrænsede områder. Det gælder især have-, bygnings- $o g$ apparaturvedligeholdelse samt rengøring, vask og kostforplejning. Det nye er snarere, at en øget inddra- 
gelse af den private sektor i den offentlige opgaveløsning anvendes bevidst som en måde, hvorpå effektiviteten kan øges - enten ved at private leverandører kan levere en given ydelse billigere end den tilsvarende offentlige leverandør eller ved, at den offentlige sektor tvinges til at levere ydelsen billigere. Sundhedssektoren blev prøvestenen for en øget privat deltagelse i tilvejebringelsen af de offentlige ydelser. I 1983 blev regionerne og distrikterne pålagt at foretage tvungne licitationer inden for rengørings-, kostforplejnings- og vaskerifunktionerne (Department of Health, 1983b). De offentlige leverandører kunne i lighed med de private byde på opgaven, men hvis de private leverandører kom med et bedre tilbud, havde regionerne og distrikterne pligt til at vælge det private tilbud.

Den foreløbige slutsten på reformeme af det engelske sundhedsvæsen blev sat med indførslen af de reformer, der blev skitseret i regeringsbetænkningen "Working for Patients" fra 1989. Kort skitseret indeholdet reformen to hovedelementer. Det første element vedrørte forholdet mellem distrikterne og sygehusene. Fra at være det sidste led $i$ den hierarkiske styringskæde blev sygehusene omdannet til uafhængige offentlige institutioner, de såkaldte "NHS-Trust". "Trust"-status indebærer, at institutionen fortsat er fuldtud offentligt ejet, men at hospitalet har egen bestyrelse, der ikke formelt er underordnet distrikts-, regions- eller andre sundhedsministerielle myndigheder, og som inden for de rammer, der sættes af lovgivning og kollektive overenskomster, har frihed til at indrette organisationen, som den finder hensigtsmæssig. Reformen indebar således, at distriktsmyndighederne ikke længere havde et ansvar for driften af hospitalerne. I stedet blev det distrikternes opgave at optræde som køber af sundhedsydelser på vegne af distriktets befolkning. Det ville fortsat i høj grad være de samme hospitaler, der skulle levere ydelserne. Men det var ideen med reformen, at distrikterne i en rolle frigjort for et egentlig driftsansvar, kunne forhandle sig frem til flere ydelser for de samme midler ved at shoppe rundt blandt de konkurrerende hospitaler i og uden for distriktet samt $i$ den egentlige private hospitalssektor. Den private sektors konkurrencemuligheder i forhold til de offentlige hospitaler blev samtidig forbedret ved, at værdien af de offentlige hospitaler blev opgjort $\mathrm{g}$ indskudt i de nyetablerede NHS-Trust. Dette offentlige indskud skulle - om end relativt lempeligt - forrentes og derfor indregnes i prisen på de offentlige hospitalers tilbud til distriktsmyndighederne.

Det andet betydelige element i reformen var en ændring af de praktiserende lægers rolle i sundhedssystemet. De praktiserende læger fik mulighed for at få en såkaldt "fundholding"-status, hvilket indebar, at den praktiserende læge kunne fă et budget til køb af en række hospitalsydelser på deres patienters vegne. Budgettet omfatter af en række mindre operationer, ambulante ydelser, diagnostiske undersøgelser, laboratorieydelser mv. De hospitalsydelser, patienterne i øvrigt vil fă brug for - først og fremmest akut behandling - skulle fortsat være omfattet af den kontrakt, distrikterne indgik med hospitaler. Ideen med indførslen af disse praksis-budgetter var at etablere en kanal, der i lighed med distrikterne skulle presse hospitaleme til at levere flere behandlinger og en bedre service inden for en given økonomisk ramme. De praktiserende læger havde på samme måde som distrikterne mulighed for at henvise deres patienter til forskellige hospitaler. De praktiserende læger havde ligeledes den mulighed selv at foretage behandlingen $i$ stedet for at henvise patienten til et hospital. Hvis den praktiserende læge derved ikke opbrugte hele budgettet til hospitalsbehandling, 
kunne beløbet anvendes til investeringer i lægens egen praksis, hvorimod beløbet ikke kunne tages ud som personlig indkomst.

Som det er fremgået, er de ændringer af det engelske sundhedsvæsen, der blev skitseret i "Working for Patients"-betænkningen, betydeligt mere omfattende og radikale end de ændringer, der blev gennemført i første del af 1980'erne. De reformer, der blev gennemført i første del af 1980'erne, anfægtede ikke grundlæggende den daværende organisering af det engelske sundhedsvæsen. De spørgsmål, reformerne behandlede var, hvor mange niveauer hierarkiet skulle indeholde; hvem der skulle bestemme på hvert niveau; hvad man kunne bestemme på hvert niveau og hvordan man skulle indrette den hierarkiske kontrol af de enkelte niveauer i organisationen - kort sagt forhold vedrørende ledelsesstruktur og budget- og kompetenceregler, der alle sammen er klassiske forvaltnings- og organisationsteoretiske emner. Der er mere New Public Management - forstået som nye forvaltningsmæssige principper - over indførslen af den tvungne licitation af en række serviceydelser, hvor såvel private som offentlige leverandører kunne byde på opgaverne. Der ligger ligeledes nye, basale principper til grund for reformerne skitseret $i$ "Working for Patients"-betænkningen. Reformerne er delvist et brud med forestillingen om, at en hierarkisk opbygning er den mest hensigtsmæssige måde at organisere sundhedsvæsenet på. Reformerne fjernede den hierarkiske relation mellem de offentlige myndigheder og serviceproducerende institutioner og indførte i princippet en kontrakt-relation mellem formelt set uafhængige købere og sælgere, der i princippet var etableret i en situation, hvor flere hospitaler konkurrerede om at levere ydelseme.

Ikke desto mindre er der også en vis sammenhæng i reformeme af det engelske sundhedsvæsen i 1980'erne. Det gælder først og fremmest sigtet med reformerne, der i alle tilfælde har været at få flere og bedre sundhedsydelser for de samme penge. Det gælder ligeledes i den forstand, at Working for Patients-reformerne ikke berører relationen mellem ministeren, og lokale statslige sundhedsmyndigheder, og at de andringer, der blev gennemført i første del af 1980'erne, fortsat er gældende: Regionerne og distrikterne er fortsat genstand for annual reviews, baseret på scoren på prestations-indikatorerne, og det overordnede ansvar på regions- og distriktsniveauer stadig henlagt til én general manager.

\section{Reformerne af det danske sundheds- vasen i 1980'erne og 1990'erne}

I lighed med hvad der var tilfældet i England, er forslagene til reformer af det danske sundhedsvæsen $\mathrm{i}$ høj grad fremkommet i regeringsbetænkninger. Det gælder i første række indenrigsministeriets betænkning "Sygehusenes organisation og økonomi" (Indenrigsministeriet, 1984). På baggrund af en analyse, der påpegede, at udviklingen i sygehusenes produktivitet havde været vigende, blev der i betænkningen stillet forslag, der har klare paralleller til de samtidige engelske reformslag. Det gælder det overordnede sigte med forslagene, der også i det danske tilfælde var at forbedre produktiviteten i sygehusvæsenet. Det gælder også det konkrete forslag om at ændre ledelsesstrukturen, hvor betænkningens flertal pegede på en model med én ansvarlig leder af hospitaleme og én administrerende overlæge på hospitalsafdelingerne - svarende til det engelske forslag om indførelsen af general managers. I lighed med den engelske Griffiths-betænkning indeholdt den danske betænkning et forslag om, at det faglige og det økonomiske ansvar skulle integreres, dvs. at ledelsen af en afdeling også skulle omfatte budgetansvar og kom- 
petence til at disponere inden for et afdelingsbudget.

Betænkningen "Praksissektorens organisation" (Indenrigsministeriet, 1986) blev også udarbejdet af et udvalg under indenrigsministeriet. I betænkningen drøftedes en række forhold, der i mere snæver forstand vedrørte praksissektoren, for eksempel hvordan den sygdomsforebyggende og sundhedspædagogiske indsats kunne øges gennem ændringer af overenskomsten mellem de praktiserende læger og sygesikringen. En af betænkningens centrale problemstillinger var imidlertid, hvordan indsatsen i almen praksis, sygehusvæsenet og de tilgrænsende opgaver i socialsektoren (for eksempel plejehjemssektoren) kunne samordnes bedre. En forbedret samordning mellem social- og sundhedsvæsenet og mellem det primære og sekundære sundhedsvæsen er selvsagt en væsentlig forudsætning for en samlet forøgelse af effektiviteten i social- og sundhedsvæsenet. Det er imidlertid karakteristisk, at betænkningen stort set ikke indeholdt nogen former for New Public Management-retorik. Betænkningens udgangspunkt var en klassisk, dansk diskussion om opgavefordelingen mellem stat, amt og kommuner, og de problemer denne opdeling kunne medføre for en hensigtsmæssig samlet offentlig indsats på social- og sundhedsområdet. Det gælder for eksempel de negative konsekvenser af "kassetænkningen", hvor det eksempelvis har været påpeget, at kommunerne har manglet økonomiske tilskyndelser til at udbygge de primærkommunale sociale- og sundhedsmæssige tilbud, der kunne mindske brugen af det amtskommunale sygehusvæsen. Betænkningen lancerede flere modeller, der kunne løse samordningsproblemet. Det blev foreslået, at finansieringen af sygehusvæsenet i større eller mindre grad skulle overtages af primærkommuneme, mens amteme fortsat skulle drive sygehusvæsenet. Det vil i realiteten sige, at betænkningen med udgangspunkt $i$ en dansk diskussion anbefalede at foretage en principiel opsplitning af køber- og producentrollen svarende til forslaget i den engelske "Working for Patients"-betænkning. Den danske betænknings forslag kan imidlertid siges at være mere vidtgående - eller om man vil, der er mere hardcore New Public Management $\mathrm{i}$ det danske forslag - da købcr- og producentrollen adskilles på forskellige administrative enheder, og ikke som i det engelske tilfælde foretages inden for samme organisation. Men New Public Management retorik og overvejelser var der ikke i betænkningen.

Udlicitering har også været behandlet $\mathrm{i}$ regeringsbetænkninger i flere omgange. Første gang i begyndelsen af 1980'erne i privatiseringsudvalgets betænkning (Administrationsdepartementet, 1983), anden gang i 1991 (Finansministeriet, 1991). Fælles for de to betænkninger er, at udliciteringer anbefales overvejet $i$ hele den offentlige sektor (stat, amter og kommuner). Anbefalingerne er således ikke specifikt rettet mod sundhedsvæsenet, men nogle af de eksempler på mulige opgaver, der kunne udliciteres, findes på dette område. Det gælder for eksempel rengøring. Det er ligeledes et fællestræk ved de to betænkninger, at baggrunden for at overveje udlicitering varønsket om at opnå en omkostningseffektivisering.

Der er således også på dette område klare paralleller til reformtiltagene i den engelske offentlige sektor og det engelske sundhedsvæsen. Det gælder både sigtet med at foretage udlicitering og de opgaver, der peges på som mulige udliciteringsemner.

\section{Er forslagene blevet til virkelighed?}

I gennemgangen af de engelske og danske reformforslag på sundhedsområdet $\mathrm{i}$ 
1980'eme og 1990'erne er der blevet peget på en rakke paralleller i sigtet med og indholdet af forslagene. Det, der kan og er blevet diskuteret, er, i hvilket omfang der er tale om New Public Management- initiativer i den forstand, at der reelt er tale om nye principper for organiseringen af den offentlige sektor. Det, der måske i endnu højere grad er værd at undersøge, er, hvorvidt forslagene i praksis er blevet gennemført og rent faktisk har virket efter den officielle hensigt - at forøge effektiviteten af den offentlige sektor. Det skyldes ikke alene, at sådanne spørgsmål er centrale emner i studiet af offentlig politik og offentlig forvaltning - uanset om det sker under overskrifterne implementeringsstudier, policyanalyser, offentlig reformpolitik mv. For så vidt angår det danske og engelske sundhedsvæsen rejser det ligeledes det mere konkrete spørgsmål om, hvordan en række forslag, der har et mere eller mindre parallelt sigte og indhold, behandles i to sundhedsvæsener, der i nogle henseender er ret ens og $i$ andre henseender er ret forskellige.

Det danske og det engelske sundhedsvæsen har en række fællestræk. Begge er offentlige sundhedsvæsener, hvor almen lægehjælp og hospitalsbehandling for alle praktiske formål er fuldtud skattefinansierede. Det er ligeledes i begge tilfælde sundhedsvæsener, der i sidste instans er politisk ledede. Der er imidlertid forskel på, hvor den politiske kompetence er placeret. Til forskel fra det statslige, engelske sundhedsvæsen er hovedparten af beslutningskompetencen $i$ det danske sundhedsvæsen placeret på decentralt niveau: Det er amterne, der driver sygehusene og betaler de offentlige sygesikringsudgifter til almen- o speciallægepraksis, tandlæge, medicin mv. Der er således ikke et over- underordnelsesforhold mellem sundhedsministeren og amtsrådene. Der er heller ikke etableret noget, der svarer hertil gennem lovgivning.
Hospitalsloven er i den henseende instruktiv. Det fastslås i loven, at det er amterne og hovedstadens sygehusfællesskab, der forestår sygehusbehandlingen i Danmark, og at de i den funktion stort kun er begrenset ved, at behandlingen er vederlagsfri for borgerne.

Det kan således synes at være en ulogisk konstellation, at reformforslagene i Danmark i høj grad er fremkommet i regeringsbetænkninger, når hovedparten af beslutningskompetencen på sundhedsområdet ikke er statslig, men amtskommunal, og der ikke $i$ betænkningerne lægges op til, at de skal gennemføres ved lov. Modsat er der mere logik $i$, at den engelske regering forestår udredninger af et sundhedsvæsen, regeringen rent faktisk har ansvaret for. Ud over at den danske konstellation af udredninger på centralt niveau og beslutningskompetence på decentralt niveau kan synes ulogisk, kunne det ligeledes, ud fra en isoleret implemeteringsbetragtning, være en mindre hensigtsmæssig konstruktion, da de danske sundhedsministre ikke har umiddelbart adgang til at instruere amterne om, at dette eller hint forslag skal gennemføres. Og uden særskilt lovgivning er det de enkelte amters suveræne beslutning, hvorvidt forslagene overhovedet skal gennemføres og i givet fald $i$ hvilket omfang og på hvilket tidspunkt, det skal ske.

Formodningen om forskellen på implemeteringseffektiviteten i Danmark og England kan i nogen grad bekræftes. Det gælder for det første gennemførslen af ledelsesreformerne, der foreslås i den engelske Griffith-betænkning fra 1983 (Department of Health, 1983a) og af det danske produktivitetsudvalg i 1984. Griffith-betænkningens forslag blev accepteret af den engelske regering, og umiddelbart efter blev der udpeget general managers på alle niveauer $i$ det engelske sundhedsvæsen. I modsætning hertil blev ledelsesreformen $\mathrm{i}$ Danmark indført $i$ et mere spredt og beher- 
sket tempo i amterne. Ti år efter forslagets fremsættelse var der således fortsat enkelte amter, hvor der ikke var indført afdelingsledelser på sygehusene (Lykkesfeldt og Christensen, 1994). Hertil kommer, at de ændringer af ledelsesstrukturen, der blev foretaget på baggrund af udvalgets betæenkning, ikke fulgte udvalgets indstilling om at udnævne danske general managers på sygehusene og sygehusenes afdelinger. I stedet var det den kollektive ledelsesmodel, der blev præsenteret $i$ betænkningen, der blev gennemført - dvs. en fælles ledelse bestående af en læge, en sygeplejerske og en administrator på sygehusniveau samt en ligeledes kollektiv ledelse bestående af en læge og en sygeplejerske på afdelingsniveau (Pallesen og Pedersen, 1994) - hvilket iøvrigt stort set svarer til den ledelsesstruktur, der var gældende i det engelske sundhedsvæsen før Griffiths-betænkningen blev gennemført.

Formodningen om en forskel i implementeringseffektiviteten i England og Danmark kan for det andet bekræftes i forhold til adskillelsen af de to tidligere integrerede roller som køber og producent af sundhedsydelser. I England bliver "Working for Patients"-betænkningen nedfældet $\mathrm{i}$ lovtekst og vedtaget i parlamentet i 1990. Det var på forhånd planlagt, at reformerne skulle iværksættes gradvist fra og med finansåret april 1991. Reformerne blev imidlertid gennemført langt hurtigere end forudsat: Allerede i 1994/95 var 96 pct. af de engelske hospitaler omdannet til NHS-Trusts (Department of Health (a), 1995). I modsætning hertil er det danske forslag fra 1986betænkningen, der også opererede med en adskillelse af køber- og producentrollen, ikke blevet hverken helt eller delvist gennemført.

Udviklingen i omfanget af private leverandørers inddragelse $i$ løsningen af sygehusopgaverne i de to lande viser derimod i mindre grad en klar tendens. Det pålæg, de engelske regions- og distriktssundhedsmyndigheder fik om at udbyde en række servicefunktioner i tvungen licitation, har haft en vis effekt. De samlede udgifter til serviceydelser leveret af private virksomheder er vokset kraftigt siden $1984 / 85$, hvor disse omkostninger beløb sig til 183 mio. $f$, mens den tilsvarende udgift i regnskabsåret 1993/94 var $555 \mathrm{mio}$. £. Opgiort som andel af de samlede driftsudgifter var stigningen imidlertid beskeden: Udgiften til private leverede serviceydelser udgjorde 2,0 pct. af de samlede driftsomkostninger i 1984/85. Det tilsvarende tal for 1993/94 var 2,7 pct. af de samlede driftsomkostninger (Department of Health(a), 1986-1995).

På grund af et delvist forskelligt konteringsprincip i Danmark og England er det ikke muligt at lave en fuldtud sammenlignelig opgørelse for udviklingen i Danmark. De udgifter, der i det danske sundhedsvæsen konteres under entreprenør- og håndværkerydelser samt øvrige momsbelagte tjenesteydelser, svarer imidlertid nogenlunde til engelske opgørelse af privat leverede serviceydelser, om end den danske opgørelse indeholder udgifter, der ikke er medtaget i den engelske statistik. Opgjort på denne måde har der ligeledes i Danmark været en vis vækst $i$ driftsudgifterne af serviceydelserne leveret af private. I 1987 var udgiften 727 mio. kr. svarende til 3,4 pct. af de samlede driftsudgifter. I 1994 var udgifterne vokset til 1.119 mio. kr., svarende til 4,1 pct. af de samlede driftsudgifter (Amtsrådsforeningen, 1989-1996). Med det forbehold at det absolutte niveau ikke er fuldtud sammenligneligt i de to lande, kan det konstateres, at omfanget af privat leverede serviceydelser er beskedent $i$ begge lande, om end der har været en vis vækst $i$ de seneste år.

Implementeringen af de stort set enslydende forslag i den engelske Griffiths-betænkning og den danske 1984-betænkning 
(Indenrigsministeriet, 1984) om, at det faglige og det økonomiske ansvar på sygehusene på en gang skulle integreres og decentraliseres, kan ligeledes ikke tages til indtægt for, at der er en markant forskel på implementeringseffektiviteten $\mathrm{i}$ de to sundhedssystemer. Det er ikke muligt at give et helt præcist billede af, $\mathrm{i}$ hvilket omfang forslaget er blevet gennemfort i de to lande. Det hænger sammen med, at det ikke er muligt at opstille et præcist kriterium for, hvad der forstås ved et egentligt decentralt budgetansvar. Det gælder både hvad angår typer af udgifter, der skal være omfattet af budgettet og den grad af dispositionsfrihed, der er til at ændre fordelingen af udgifterne. Omvendt tager man formentlig ikke meget fejl ved at antage, at forslaget er blevet gennemført senere og i mere begrænset omfang end forslagene til ændringer af ledelsesstrukturen, der ligeledes var indeholdt i de to betænkninger. Det gælder i såvel Danmark som i England. Selv om den engelske regering bifaldt indholdet af Griffith-betænkningen, gik der tre år før NHS tog noget, der minder om et initiativ til at gennemføre forslaget. I 1986 blev der gennemført forsøg på et mindre antal sygehuse, der skulle belyse mulighederne og problemerne ved at decentralisere budgetansvaret inden for sygehusene (Packwood, Keen og Buxton, 1991). Forslaget nåede ikke at blive gennemfort inden Working for Patients-reformeme medførte, at forslaget i én forstand ikke længere var relevant. Omdannelsen af hospitaleme til de formelt set uafhængige NHS-Trust betød, at kompetenceforholdene og ressourcestyringen på hospitalerne ikke længere var en sag for NHS's centrale ledelse. Omvendt betød de interne markedsreformer, at behovet for at tilrettelægge en hensigtsmæssig intern ressourcestyring på hospitaleme blev aktualiseret for de nye Trust-ledelser. Efter indførslen af Working for Patients-reformeme i 1991 blev det blot- lagt, at de eksisterende informationssystemer kun i meget begranset omfang kunne levere disse oplysninger, hvilket var en medvirkende årsag til, at de kontrakter, der blev indgået mellem distriktsmyndighederne og hospitalerne i det interne markeds første år, var meget generelle og i beskedent omfang opdelt på specialetype (Appleby et al., 1993). Det kan ligeledes heraf sluttes, at der ikke har været gennemført decentral budgetansvar inden for hospitalerne i nævneværdigt omfang forud for 1991. En nødvendig - men ikke tilstrækkelig betingelse - for et decentralt budgetansvar med et reelt indhold er, at det er muligt at rapportere indtægter, udgifter og aktiviteter på det afdelings- eller specialeniveau, der er omfattet af budgetansvaret.

Sammenfattende kan det således konkluderes, at den forskellige opbygning af det engelske og danske sundhedsvæsen $i$ et vist omfang har betydning for den effektivitet, hvormed reformforslagene er blevet implementeret. I to af de fire foreslåede ændringer vedrørende ledelsesstrukturen og den formelle adskillelse af køber- og producentrollerne - er reformerne blevet mere effektivt implementeret i det centralt styrede engelske system end i det decentral opbyggede danske sundhedsvæsen. I de to øvrige tilfælde - forslagene om decentralt budgetansvar og øget brug af private underleverandører i sygehusvæsenet - er der tale om nogenlunde samme udvikling i de to lande.

Resultatet illustrerer således både det centralt organiserede systems implementeringsstyrke og begrænsning. Enkle og veldefinerede ændringer, som indførslen af en ny stillingskategori - general manager - eller en ændring af hospitalernes juridiske status til formelt set uafhængige offentlige institutioner, kan gennemføres med stor effektivitet. Gennemførslen af sådanne forslag kræver ikke nogen videre fortolkning og er lette at kontrollere. Når det derimod gælder 
effektiviteten i gennemførslen af reformer som decentralt budgetansvar eller øget udlicitering, er der ikke nævneværdig forskel på det centralt styrede engelske og det decentralt organiserede danske sundhedsvæsen. I disse tilfælde er centralt udstedte, generelle foreskrifter enten meningsløse eller giver de reelt implementerende, nederste lag i hierarkiet store fortolkningsmuligheder. Det er i særlig grad relevant, hvis sigtet med forslagene ikke deles af de nederste lag i hierarkiet. Disse generelle styringsmæssige komplikationer kan bidrage til at forklare, hvorfor eksempelvis omfanget af private underleverandører ikke er vokset synderligt på trods af direktivet om at arrangere tvungne, fair licitationer på en række serviceområder inden for det engelske sundhedsvæsen. Forslaget blev mødt med åben modstand fra de offentligt ansatte og fagforeningerne på de områder, der blev berørt af forslaget. Distriktsmyndighederne og hospitalsledelserne modsatte sig ikke åbent direktivet. Det forhold, at omkring 85 pct. af licitationerne blev vundet af de offentligt ansatte viser imidlertid, enten at offentlig drift stort set altid er mere effektivt end privat eller, at omkostningsberegninger i den offentlige sektor er manipulerbare (Ranade og Haywood, 1991).

Ud over at eksemplerne demonstrerer forskellene og lighederne på et centralt og decentralt organiseret systems implemeteringseffektivitet, leder det også for begges landes vedkommende frem til det overordnede spørgsmål, om reformerne rent faktisk har haft en effekt i den forstand, at omkostningsudviklingen er modereret og produktiviteten er forøget, jf. Hoods syvende og afgørende kriterium for overhovedet at iværksætte New Public Managementinitiativerne. En forste indlysende forudsætning for, at reformerne kan have en effekt på omkostnings- og produktivtetsudviklingen er, at reformforslagene er blevet gen- nemført og ikke blot er forblevet forslag. En anden indlysende forudsætning for, at et reformforslag kan have en effekt, er, at reformerne er effektive midler til at nå de opstillede mål. Som det er fremgået, er der for det første en række af de forslag, der er blevet fremsat med det sigte at forbedre effektiviteten af det engelske og danske sundhedsvæsen, der ikke er nået videre end forslagsstadiet. For det andet er de forslag, der er blevet gennemført, ikke dem, der på forhånd kan forventes at have den største effekt. I begge lande er det de reformer, der overordnet kan karakteriseres som strukturreformer, der i videst omfang er blevet gennemført. Derimod er de reformer, der havde som sigte at påvirke adfærden via ændrede incitamenter, kun i begrænset omfang blevet gennemført.

Der er således på forhånd grund til at nære en vis skepsis, om de reformer afdelingsledelse- og budgetereformen i Danmark og Working for Patients-reformerne i England - der må betegnes som de mest centrale i de to lande, har haft en effekt på omkostnings- produktivitetsudviklingen. Spørgsmålet er dog i sidste instans empirisk, og det behandles nedenfor.

\section{Effekten af de engelske reformer - omkostninger og produktivitet}

Det er ikke ligetil at vurdere, hvorvidt sundhedsreformerne har haft en effekt på omkostningsudviklingen. Det skyldes, at funktioner flyttes til og fra sygehusvæsenet, $o g$ at principperne for budget- og regnskabsaflæggelse af og til ændres. Indførslen af Working for Patients-reformerne i England indebar, at opgørelsen af ressourceforbruget blev markant ændret. Det betyder, at der skal foretages en række korrektioner for at få opgjort udviklingen $\mathrm{i}$ ressourceforbruget på en måde, der gør det muligt at foretage en sammenligning over tid. Efter korrektion for 
ændrede funktioner $\mathrm{og}$ ændrede budget- og regnskabsprincipper kan det konstateres, at engelske reformer, der blev gennemført fra og med 1991 ikke har medført, at væksten ide samlede sygehusudgifter er blevet dæmpet.

Tværtimod har gennemførslen afWorking for Patients-reformerne været ledsaget af en ganske betydelig vækst i ressourceforbruget. Opgiort i faste priser steg sygehusudgifterne med ca. 14 pct. i de forste tre år efter reformerne blev indført. I tre-års perioden umiddelbart for reformeme blev gennemført, var der til sammenligning en mere beskeden vækst i sygehusudgiften på ca. fire pct.

Den kraftige vækst i ressourceforbruget er ikke nødvendigvis ensbetydende med, at reformerne også har været en fiasko, for så vidt angår udviklingen i produktiviteten. Det fordrer imidlertid, at væksten i aktiviteterne eller outputtet har været endnu kraftigere end væksten iudgifterne. Sygehusvæsenets aktivitet er traditionelt blevet målt på en række indikatorer. I Danmark har antallet af udskrivninger, sengedage og ambulante besøg været anvendt som indikatorer. I England anvendes et sæt af indikatorer, der stort set svarer til de danske. En opgørelse af aktiviteten i sygehusvæsenet baseret på disse indikatorer er på flere måder problematisk. Indikatoreme kan for det første ikke opfange ændringer i tyngden og kvaliteten af behandlingsaktiviteten. For det andet er det problematisk at sammenveje indikatoreme til et enkelt mål for aktiviteten, da antallet af indlæggelser og ambulante besøg har været stigende, mens antallet af sengedage har været faldende.

Indførelsen af Working for Patients-reformerne har imidlertid haft den sideeffekt, at problemerne med anvendelsen af de traditionelle aktivitetsindikatorer er blevet reduceret. Hospitaleme er i stigende omfang begyndt at prissætte deres ydelser, hvilket $i$ realiteten betyder, at det $i$ højere grad er muligt at vurdere den relative værdi af hospitalernes forskellige ydelser. I tabel 1 er aktivitetsudviklingen eller det samlede output i det engelske sygehusvæesen beregnet med udgangspunkt $i$ en prisliste fra et engelsk hospital - der er typisk både hvad angår størrelse og specialiseringsgrad.

Som det fremgår af tabel 2 er konklusionen vedrørende aktivitetsudviklingen stærkt afhængig af, hvorvidt udviklingen i antallet af sengedage medtages $i$ beregningen af outputtet. Hvorvidt sengedage bør indgå $i$ beregningen kan diskuteres. Det ændrer imidlertid ikke ved det forhold, at uanset om antallet af sengedage indgår $\mathrm{i}$ beregningen af den samlede aktivitet eller ej, så er konklusionen vedrørende tendensen $\mathrm{i}$ produktvitetsudviklingen den samme jf. tabel 3 .

Inkluderes antallet af sengedage i aktivitetsopgørelsen - og dermed i opgørelsen af produktiviteten - er konklusionen, at produktiviteten har været kraftigt faldende i perioden 1987/88 - 1993/94. Medtages antallet af sengedage ikke $\mathrm{i}$ aktivitetsopgørelsen er konklusionen, at produktiviteten i det engelske sygehusvæsen har været svagt faldende i perioden. Men i forhold

Tabel 1. Sygehusudgifter, England 1987/88 - 1993/94. Index, faste priser. Korrigeret for ændrede funktioner og ændrede budget- og regnskabsprincipper

\begin{tabular}{|r|r|r|}
\hline $1987 / 88$ & $1990 / 91$ & $1993 / 94$ \\
\hline 100.00 & 103.7 & 118.4 \\
\hline
\end{tabular}

Kilde: Department of Health, The Governments Expenditure Plans, 1989/90-1995/96. 
Tabel 2. Aktivitetsudvikling, England, 1987/88 - 1993/94. Med og uden udviklingen i sengedage

\begin{tabular}{l|r|r|r|}
\hline & $1987 / 88$ & $1990 / 91$ & $1993 / 94$ \\
\hline Inklusive sengedage & 100 & 91 & 86 \\
Eksklusive sengedage & 100 & 103 & 112 \\
\hline
\end{tabular}

Kilde: Department of Health, Health and Personal, Social Services Statistics for England, 1989-1995.

til vurderingen af produktivitetsudviklingen før og efter gennemførelsen af de engelske reformer er denne nuanceforskel uden betydning: I begge tilfælde er faldet i produktiviteten større efter end før indførelsen af reformerne.

Forklaringen på udfaldet af de engelske reformer skal søges i flere forhold (Pallesen, 1997). I de treårige budgetoverslag, der blev vedtaget $i$ forbindelse med introduktionen af reformerne, blev udgiftsniveauet øget i forhold til tidligere. Den faktiske udgiftsudvikling blev imidlertid endnu kraftigere end forudsat $i$ budgetoverslagene. Det skyldes, at parlamentet i de første år efter reformernes vedtagelse, $i$ de afsluttende budgetforhandlinger før det enkelte budget trådte $i$ kraft, flere gange justerede budgetterne opad. Politikernes faktiske budgetadfærd svarede således i realiteten ikke til ambitionen om at holde udgifterne på niveau med eller under omkostningsudviklingen før indførelsen af reformerne. Forklaringen på den engelske regerings udgiftspolitik på sundhedsområdet skal formentlig ligeledes søges i flere omstændigheder. En mulig forklaring er, at regeringen reage- rede på den kraftige kritik af sundhedsreformerne. Reformerne blev ikke alene kritiseret af oppositionen og de sundhedsfaglige organisationer, meningsmålinger indikerede også, at der blandt flertallet af vælgerne var en udbredt skepsis over for den konservative regerings politik på sundhedsområdet. Forklaringen støttes af, at det specielt var i de første år efter reformens vedtagelse, at sundhedsbudgetterne blev øget - dvs. op til parlamentsvalget i 1992. En anden mulig forklaring på udviklingen er, at NHS de facto ikke overholdt de vedtagne budgetter, hvilket også i særlig grad var tilfældet i de første år efter reformernes vedtagelse. De to forklaringer - deres forskelligheder til trods - kan udmærket supplere hinanden: De ansatte medarbejdere og ledere i NHS kan have vurderet, at det $i$ en politisk situation, hvor den sundhedspolitiske kritik af regeringen var kraftig, var det mindre risikabelt at sætte budgetterne og de politiske bevillingsgivere under pres.

Årsagerne til den vigende produktivitet kan overordnet tilskrives den omstændighed, at det interne markedsprincip om at etablere en stærkere sammenhæng mellem

Tabel 3. Produktivitetsudvikling, England, 1987/88 - 1993/94. Med og uden udviklingen $i$ sengedage

\begin{tabular}{|l|c|c|c|}
\hline & $1987 / 88$ & $1990 / 91$ & $1993 / 94$ \\
\hline Inklusive sengedage & 100 & 88 & 73 \\
Eksklusive sengedage & 100 & 99 & 95 \\
\hline
\end{tabular}

Kilde: Tabel 1 og 2. 
Tabel 4. Udgiftsudvikling. Fyns og Århus Amt, alle amter. Faste priser. Korrigeret for funktionsændringer mv. Index 1987=100

\begin{tabular}{|l|c|c|c|}
\hline & 1987 & 1990 & 1994 \\
\hline Fyns Amt & 100 & 107,4 & 118,8 \\
Århus Amt & 100 & 99,7 & 108,7 \\
Alle Amter* & 100 & 102,5 & 109,2 \\
\hline
\end{tabular}

Kilde: Amtsrådsforeningen, Amternes Økonomi, Budget 1989-1996

* Alle amter med undtagelse af Bornholms Amt, Københavns og Frederiksberg Kommune.

udgifts- og ydelsesomfanget ikke blev gennemført. Tværtimod udviklede produktiviteten sig mere uensartet i de enkelte regioner efter indførelsen af reformerne. De regioner, der havde den relativt bedste aktivitetsudvikling blev ikke af den grund budgetmæssigt begunstiget $i$ forhold til de regioner, hvor aktiviteten udviklede sig relativt dårligere. Basalt set kolliderede princippet om at etablere en stærkere sammenhæng mellem udgifts- og ydelsesomfang med en parallel politisk målsætning om at udligne regions- og distriktsforskellene $\mathrm{i}$ bevillingsniveauet per inbygger. Den politiske målsætning om at udligne bevillingsniveauet havde i realiteten den konsekvens, at incitamentet til at øge produktiviteten blev begrænset, da størrelsen af regionernes og distrikternes bevillinger $i$ højere grad blev gjort afhængig af indbyggertallet end af udviklingen $\mathrm{i}$ aktivitetsomfanget.

\section{Effekten af de danske reformer - omkostninger og produktivitet}

Den decentrale opbygning af det danske sundhedsvæsen har betydet, at de enkelte amter har gennemført afdelingsledelse- og afdelingsbudgetreformerne i stærkt varierende omfang og på ganske forskellige tidspunkter. I relation til at vurdere, hvorvidt reformerne har haft en effekt på omkostnings- og produktivitetsudviklingen, er det imidlertid en frugtbar situation: Det er ikke alene muligt at sammenligne udviklingen $\mathrm{i}$ det enkelte amt før og efter indførelsen af reformerne. Det er ligeledes i et vist omfang muligt at sammenligne udviklingen $\mathrm{i}$ de amter, der har gennemfort reformerne i fuldt omfang med de amter, der ikke - eller kun delvist - har gennemført ændringerne.

Fyns og Århus Amt gennemførte som de første amter reformerne i fuldt omfang. I begge tilfælde blev der indført afdelingsledelse med budgetansvar fra og med 1991. Hvis den første, amts-interne komparative standard lægges til grund, så har reformeme i Fyns og Århus Amt ikke været en succes. I begge amter steg sygehusudgifterne efter indførelsen af reformerne, jf. tabel 4. Aktivitetsomfanget faldt $\mathrm{i}$ begge amter $\mathrm{i}$ perioden før reformerne blev indført, mens det var stagnerende i perioden efter reformerne blev introduceret, jf. tabel 5. Samlet var det ensbetydende med, at produktiviteten var vigende i begge perioder, jf. tabel 6 . Dette indtryk af manglende reformsucces bliver imidlertid i nogen grad modificeret, hvis udviklingen i de to amter sammenlignes med udviklingen i de øvrige danske amter: Udviklingen i udgiftsniveauet, aktivitetsomfanget og produktiviteten i Fyns og Århus Amt i perioden efter 1990 adskiller sig ikke væsentligt fra udviklingen i de øvrige danske amter.

Også hvad angår forklaringerne på resultatet af de danske reformer, kan der findes paralleller til den engelske udvikling. 
Tabel 5. Aktivitetsudvikling*. Fyns og Århus Amt, alle amter. Faste priser. Korrigeret for funktionsændringer mv. Index 1987=100

\begin{tabular}{|l|r|r|r|}
\hline & 1987 & 1990 & 1994 \\
\hline Fyns Amt & 100 & 91 & 90 \\
Arhus Amt & 100 & 91 & 90 \\
Alle Amter** & 100 & 92 & 90 \\
\hline
\end{tabular}

Kilde: Sundhedsstyrelsen, Virksomheden ved sygehusene, 1987-1994

* Sammenvejning af aktivitetsindikatoreme er foretaget med udgangspunkt $i$ en sundhedsfaglig vurdering af den relative vægt af de enkelte aktivitetsindikatorer, se Pallesen (1997).

** Alle amter med undtagelse af Bornholms Amt, Københavns og Frederiksberg Kommune.

De budgetterede sygehusudgifter er blevet forøget. Til trods for dette har reformerne ikke bidraget til, at budgetterne i højere grad end tidligere er blevet overholdt. I lighed med, hvad der var tilfældet i England, har reformerne heller ikke bidraget til, at der er blevet etableret en stærkere sammenhæng mellem udgifts- og ydelsesomfanget. Også i Danmark må det politiske niveau tilskrives et væsentligt medansvar for, at det ikke har været tilfældet. Afdelingsbudgetsystemet, der i princippet søgte at etablere stærkere sammenhæng mellem afdelingernes udgifter og aktivitetsomfang, er ikke blevet understøttet af en tilsvarende sammenhæng mellem aktiviteten og udgiftsniveauet på hospitalsniveauet. Det gælder hverken i de oprindelige sygehusbudgetter eller i de ofte mange hundrede tillægsbevillinger, der årligt sanktioneres på det amtspolitiske niveau.
Afslutning
Artiklen har søgt at belyse, hvorvidt de re- former, der er blevet gennemført af sund- hedsvæsenet i Danmark og England i 1980'erne og 1990'erne, afspejler indhol- det af og formålet med de reformer, der er omfattet af New Public Management-begre- bet. Det kan diskuteres, hvor veldefineret New Public Management-begrebet er, og hvorvidt det indeholder særligt originale ele- menter. Ikke desto mindre har flere af de reformforslag, der er blevet drøftet i det en- gelske og danske sundhedsvæesen, en række fællestræk, der både hvad angår mål og midler, relativt tvangfrit kan kategoriseres

Tabel 6. Produktivitetsudvikling. Fyns og Århus Amt, alle amter. Faste priser. Index $1987=100$

\begin{tabular}{|l|r|r|r|}
\hline & 1987 & 1990 & 1994 \\
\hline Fyns Amt & 100 & 84 & 76 \\
Århus Amt & 100 & 91 & 82 \\
Alle Amter* & 100 & 91 & 82 \\
\hline
\end{tabular}

Kilde: Baseret på tabel 4 og 5 .

* Alle amter med undtagelse af Bornholms Amt, Københavns og Frederiksberg Kommune 
som New Public Management-initiativer. Det er i sig selv bemærkelsesværdigt, da de to landes sundhedsvæsener i nogle henseender er forskelligt opbyggede. Den forskellige opbygning har i et vist omfang betydning for den effektivt, hvormed forslagene implemeteres i de to lande. Ikke desto mindre er resultaterne af reformerne bemærkelsesværdigt parallelle. I den henseende er der imidlertid ikke så meget New Public Management over de to landes sundhedsreformer: Resultatet af reformbestræbelserne målt på udgifts- eller produktivitetsudviklingen er ikke imponerede. Udfaldet af reformerne kan måske snarere ses som et udslag af "Old Public Sector Politics", hvad enten det gælder de politisk valgte lederes evne og vilje til at fastholde deres oprindelige målsætninger eller de offentligt ansatte og de offentlige lederes muligheder for at påvirke de politisk fastsatte målsætninger.

\section{Litteratur}

Administrationsdepartmentet (1983). "Rapport fra privatiseringsudvalget", København: Finansministeriet.

Amtsrådsforeningen (diverse årgange). "Amternes Økonomi - Budget", København: Amtsrådsforeningen i Danmark.

Appleby, John, Paula Smith, Wendy Ranade, Val Little og Ray Robinson (1993). "Monotoring Managed Competition", i Ray Robinson og Julian Le Grand (eds.), Evaluating the NHS Reforms, Newbury: Kings Fund Institute.

Department of Health (1983a). "NHS Management Inquiry" Report, London: DoH.

Department of Health (1983b). "Competetive Tendering in the Provision of Domestic, Catering and laundry Services", Health Circular 83(18), London: DoH

Department of Health (1989). "Working for Patients", London: HMSO

Department of Health(a) (diverse årgange). The
Governments Expenditure Plans, London: HMSO.

Department of Health(b) (diverse årgange). Health and Personel Social Services Statistics for England, London: HMSO.

Finansministeriet (1991). "Udlicitering af offentlige drifts- og anlægsopgaver", Betænkning nr. 1227, Kobenhavn: Finansministeriet.

Gulick, Luther (1937). "Notes on the Theory of Organization", i L. Gulick og L. Urwick, Papers on the Science of Administration, New York: Institute for Public Administation

Hood, Christopher (1991). "A Public Management for All Seasons", Public Administration, 69 , pp. 3-19

Indenrigsministeriet (1984). "Sygehusenes organisation og økonomi", København: Indenrigsministeriet.

Indenrigsministeriet (1986). "Praksissektorens organisation", Betænkning nr. 1080, København, Indenrigsministeriet

NAHA (1985). The National Association of Health Authorities in England and Wales: NHS Handbook, Birmingham: NAHA.

Lykkesfeldt, Gert og Ingrid Christensen (1994). "Afdelingsledelse på kliniske og tværgående sygehusafdelinger", DSI Rapport 94.01, København: Dansk Sygehus Institut.

Packwood, Tim, Justin Keen og Martin Buxton (1991). Hospitals in Transition. The Ressource Management Experiment, Philadelphia: Open University Press.

Pallesen, Thomas (1997). Health Care Reforms in Britain and Denmark: The Politics of Economic Success and Failure, Arhus: Institut for Statskundskab.

Pallesen, Thomas og Lars Dahl Pedersen (1994). „Ledelsesreformer på sygehusene: Fra produktivitetsudvikling til afdelingsbudgetter", Politica, 26. årg., nr. 3, pp. 299-312.

Ranade og S. Haywood (1991). "Privatisation from Within: The National Health Service under Thatcher", pp. 91-110 i C. Altenstetter og S. Haywood (eds.), Comparative Health Policy and the New Right, London: MacMillan.

Ståhlberg, Krister (1996). "Utvecklingspolitiken i finländska kommuner", paper præsenteret ved den Nordiske Statskundskabskongres august 1996, Åbo: Ábo Akademi. 
som New Public Management-initiativer. Det er i sig selv bemærkelsesværdigt, da de to landes sundhedsvæsener i nogle henseender er forskelligt opbyggede. Den forskellige opbygning har i et vist omfang betydning for den effektivt, hvormed forslagene implemeteres i de to lande. Ikke desto mindre er resultaterne af reformerne bemærkelsesværdigt parallelle. I den henseende er der imidlertid ikke så meget New Public Management over de to landes sundhedsreformer: Resultatet af reformbestræbelserne målt på udgifts- eller produktivitetsudviklingen er ikke imponerede. Udfaldet af reformerne kan måske snarere ses som et udslag af "Old Public Sector Politics", hvad enten det gælder de politisk valgte lederes evne og vilje til at fastholde deres oprindelige målsætninger eller de offentligt ansatte og de offentlige lederes muligheder for at påvirke de politisk fastsatte målsætninger.

\section{Litteratur}

Administrationsdepartmentet (1983). "Rapport fra privatiseringsudvalget", København: Finansministeriet.

Amtsrådsforeningen (diverse årgange). "Amternes Økonomi - Budget", København: Amtsrådsforeningen i Danmark.

Appleby, John, Paula Smith, Wendy Ranade, Val Little og Ray Robinson (1993). "Monotoring Managed Competition", i Ray Robinson og Julian Le Grand (eds.), Evaluating the NHS Reforms, Newbury: Kings Fund Institute.

Department of Health (1983a). "NHS Management Inquiry" Report, London: DoH.

Department of Health (1983b). "Competetive Tendering in the Provision of Domestic, Catering and laundry Services", Health Circular 83(18), London: DoH

Department of Health (1989). "Working for Patients", London: HMSO

Department of Health(a) (diverse årgange). The
Governments Expenditure Plans, London: HMSO.

Department of Health(b) (diverse årgange). Health and Personel Social Services Statistics for England, London: HMSO.

Finansministeriet (1991). "Udlicitering af offentlige drifts- og anlægsopgaver", Betænkning nr. 1227, Kobenhavn: Finansministeriet.

Gulick, Luther (1937). "Notes on the Theory of Organization", i L. Gulick og L. Urwick, Papers on the Science of Administration, New York: Institute for Public Administation

Hood, Christopher (1991). "A Public Management for All Seasons", Public Administration, 69 , pp. 3-19

Indenrigsministeriet (1984). "Sygehusenes organisation og økonomi", København: Indenrigsministeriet.

Indenrigsministeriet (1986). "Praksissektorens organisation", Betænkning nr. 1080, København, Indenrigsministeriet

NAHA (1985). The National Association of Health Authorities in England and Wales: NHS Handbook, Birmingham: NAHA.

Lykkesfeldt, Gert og Ingrid Christensen (1994). "Afdelingsledelse på kliniske og tværgående sygehusafdelinger", DSI Rapport 94.01, København: Dansk Sygehus Institut.

Packwood, Tim, Justin Keen og Martin Buxton (1991). Hospitals in Transition. The Ressource Management Experiment, Philadelphia: Open University Press.

Pallesen, Thomas (1997). Health Care Reforms in Britain and Denmark: The Politics of Economic Success and Failure, Arhus: Institut for Statskundskab.

Pallesen, Thomas og Lars Dahl Pedersen (1994). „Ledelsesreformer på sygehusene: Fra produktivitetsudvikling til afdelingsbudgetter", Politica, 26. årg., nr. 3, pp. 299-312.

Ranade og S. Haywood (1991). "Privatisation from Within: The National Health Service under Thatcher", pp. 91-110 i C. Altenstetter og S. Haywood (eds.), Comparative Health Policy and the New Right, London: MacMillan.

Ståhlberg, Krister (1996). "Utvecklingspolitiken i finländska kommuner", paper præsenteret ved den Nordiske Statskundskabskongres august 1996, Åbo: Ábo Akademi. 